\title{
Decreased osteoblastogenesis from synovial fluid progenitors as a marker of systemic inflammatory process in juvenile idiopathic arthritis
}

\author{
E Lazic Mosler ${ }^{1 *}$, M Jelusic-Drazic ${ }^{2}$, D Grcevic ${ }^{1}$, A Marusic $^{3}$, N Kovacic $^{1}$ \\ From 18th Pediatric Rheumatology European Society (PReS) Congress \\ Bruges, Belgium. 14-18 September 2011
}

\section{Background}

Juvenile idiopathic arthritis (JIA) is characterized by synovial hyperplastic changes, which may contribute to joint destruction by inhibiting osteoblastogenesis.

\section{Aims}

The aims of this report are: 1) to assess osteoblastogenesis from synovial fluid (SF) progenitors in children with JIA, 2) to assess the effect of SF from patients with JIA on osteoblastogenesis from bone marrow (BM) progenitors, and 3) to assess local and systemic expression of OBL related genes in JIA.

\section{Methods}

Peripheral blood (PB) samples were obtained from children with oligoarticular JIA (oJIA, $n=18$ ), polyarticular JIA (pJIA, $n=20$ ), and healthy controls $(n=18)$. SF samples were collected from children with oJIA $(n=20)$ and pJIA $(\mathrm{n}=7)$. Osteoblastogenesis was induced with $50 \mu \mathrm{g} / \mathrm{ml}$ ascorbic acid and $5 \mathrm{mmol} \beta$-glycerophosphate, in SF cells and BM cells obtained from a healthy donor, and assessed by alkaline phosphatase (AP) histochemistry. Gene expression of Runx-genes, osteoprotegerin (OPG) and receptor activator of nuclear factor $-\kappa \mathrm{B}$ ligand (RANKL) was analyzed by qPCR.

\section{Results}

Osteoblastogenesis from SF cells was higher in children with oJIA, than in pJIA (784.81 \pm 216.79 vs. $257.21 \pm 68.13$ units, $\mathrm{p}<0.001$, $t$-test), and negatively correlated with erythrocyte sedimentation rate $(\rho=-0.4139, p=0.03)$. SF from children with oJIA and pJIA inhibited osteoblastogenesis

\footnotetext{
* Correspondence: elvira.lazic@mef.hr

${ }^{1}$ University of Zagreb School of Medicine, Zagreb, Croatia

Full list of author information is available at the end of the article
}

from bone marrow $(0.059 \pm 0.026$ in oJIA; $0.068 \pm 0.019$ in pJIA vs. $0,115 \pm 0,023$ in untreated cultures, $\mathrm{p}<0.05$, t-test). Expression of Runx1 and RANKL was higher in SF cells from pJIA than from oJIA patients $(\mathrm{p}<0.05$, MannWhitney test).

\section{Conclusion}

Osteoblast differentiation is locally inhibited in JIA, particularly in children with pJIA, and correlate with systemic inflammatory activity.

\section{Author details}

${ }^{1}$ University of Zagreb School of Medicine, Zagreb, Croatia. ${ }^{2}$ University Hospital Centre, Zagreb, Croatia. ${ }^{3}$ University of Split School of Medicine, Split, Croatia.

Published: 14 September 2011

doi:10.1186/1546-0096-9-S1-P311

Cite this article as: Mosler et al: Decreased osteoblastogenesis from synovial fluid progenitors as a marker of systemic inflammatory process in juvenile idiopathic arthritis. Pediatric Rheumatology 2011 9(Suppl 1): P311.

Submit your next manuscript to BioMed Central and take full advantage of:

- Convenient online submission

- Thorough peer review

- No space constraints or color figure charges

- Immediate publication on acceptance

- Inclusion in PubMed, CAS, Scopus and Google Scholar

- Research which is freely available for redistribution 